\title{
Impact and Challenges of GST in India with Reference to Media \& Entertainment Sector - An Insight
}

\section{Sudipta Chakraborty}

Assistant Professor in Commerce

Xavier Law School

St. Xavier's University, Kolkata

Contact No.: 9836417323

E-mail: chakrabortysudipta1993@gmail.com 


\begin{abstract}
$\underline{\text { Abstract }}$
The biggest tax reform since independence i.e., Goods and Services Tax (GST) has now become a part of Indian economy from $1^{\text {st }}$ July, 2017. It is a comprehensive indirect tax on manufactures, sales and consumption of goods and services; thereby subsuming almost all other indirect taxes that were in existence throughout India before its implementation and also eliminating the cascading effects thereby. GST was introduced just after demonetisation in November, 2016 and has changed the whole scenario of indirect tax system in India. It aims at boosting overall growth of Indian economy by integrating all indirect taxes into one. The media and entertainment $(M \& E)$ industry in India is one of the fastest growing sectors and has outperformed expectations in recent years. With the expansion of the economy, the sector has accelerated its growth. The sector spreads into big and small screens, media, events, exhibitions, amusement facilities and gaming zones, with various combinations of offline and online delivery systems. With the advent of GST, things have become relatively simpler for the entertainment industry as it is subjected to only one tax and permissible local body taxes. One of the major changes has been the subsuming of Entertainment Tax under GST. Earlier, prior to implementation of GST, the rate of Entertainment Tax for the film industry varied from state to state, ranging from $15 \%$ to $110 \%$. Introduction of GST has stabilised the rate variance and provided a uniform market across the nation. In this study, we have also made an attempt to study the pre and post GST effects on different activities of the media and entertainment industry like exhibition of movies, food and beverages sold at movie halls, services rendered by artists and other technician, sponsorship and brand promotion and advertisement. Thus, this paper is an endeavour to understand the impact of GST on media and entertainment sector and aims at pointing out the challenges of the same under the present structure and provide some way outs to it.
\end{abstract}

Keywords: Goods and Services Tax, Media \& Entertainment, Impact, Challenges, Way outs. 


\section{Introduction}

\subsection{A brief history and roadway of GST in India}

The $122^{\text {th }}$ Amendment Bill of the Constitution of India introduced a national Goods and Services Tax in India from $1^{\text {st }}$ July 2017. The GST law has changed the whole scenario of indirect tax system. It is considered as biggest tax reform since 1947, combining almost fifteen indirect taxes into one-fold, except alcoholic liquor for human consumption and five petroleum products on which the erstwhile duties continue. Electricity and real estate, except supply of construction services have also been kept outside the purview of GST. The introduction of such a tax in Indian Economy is a concrete step of Government of India as one of the biggest taxation reforms and is aims to integrate State economies and boost overall growth. The process began way back in 2004 with the recommendations of the Kelkar task force that gave a proposal of such an introduction. However, it required agreement from all the states and in the parliament for its implementation. The major hurdle of passing of the GST bill was in the Rajya Sabha where there was a major dilemma and the bill got blocked several times owning to the back out of the majority parties at the last moment and the house getting dissolved. However, after lot of tugging, the bill finally got passed in 2017 and implemented with effect from 1st July 2017. With lot of expectation at the kick off, the bill seems to set the ball rolling towards an easy and simple tax structure.160 countries in the world including Australia, New Zealand, Brazil and Canada have already implemented this tax system, France being the first country to introduce it. The concept of GST adopted in India is quite unique as it is based on 'dual model' where tax is levied parallel by both the central government and state government. There is a uniform tax incidence under GST, i.e. 'supply' of goods and/or services. GST in India consists of Central GST (CGST), State GST (SGST), Union Territory GST (UTGST) and Integrated GST (IGST). While CGST is collected by the Central Government and SGST is collected by respective State Governments, UTGST and IGST are collected by the Centre and the Union Territories respectively. The rate of tax varies from nil, $5 \%, 12 \%, 18 \%$ to $28 \%$, topped up by a compensation cess of up to $15 \%$ (in general) on certain goods. Though GST is not a panacea to all the complications and problems Indian taxation system suffers with, yet it aims at reducing tax evasion and cascading effect to make the taxation system more simplified and business friendly.

\subsection{Media and Entertainment Sector in India}


The entertainment industry consists of different segments under its folds namely television, print, and films etc. It also includes smaller segments like radio, music, gaming and visual effects, animation, and internet advertising. Entertainment industry in India has registered a huge growth in last two decades and is one of the fastest growing industries in India, backed by rising consumer demand and improving advertising revenues. India is one of the fastest growing and highest spending advertising market globally. The projected growth of Indian media \& entertainment sector is estimated at a Compound Annual Growth Rate (CAGR) of $14.3 \%$ to touch Rs. 2.26 trillion (US $\$ 33.9$ billion) by 2020 , while revenues from advertising is expected to grow at $15.9 \%$ to Rs. 99,400 crores (US\$14.91 billion). Growth in the field of television advertising alone is expected at a CAGR of 15\% between 2015 and 2020, while print media is expected to grow at $8.6 \%$, according to a report by consulting firm KPMG and FICCI (Federation of Indian Chambers of Commerce and Industry). The industry has been largely driven by increasing digitalisation and higher internet usage over the last decade. Internet has become a mainstream media for a basket full of various types of entertainments for most of the people at recent times. While the growth track is quite impressive, a number of challenges are also posed by the industry. The implementation of GST impacts on the sector and its components like broadcasting, print, television, digital etc. One of the major changes has been the subsuming of Entertainment Tax under GST. Earlier, prior to GST, the rate of Entertainment Tax for the film industry varied from state to state, ranging from 15\% to $110 \%$. Introduction of GST has stabilised the rate variance and provides a uniform market across the nation. A GST of $18 \%$ is levied on movie tickets up to Rs. 100, and $28 \%$ on movie tickets costing more than Rs. 100. The uniform rate across the nation does not allow any possibility of arbitrage. Cinema has long been synonymous with the M\&E sector in India. There is a long value chain in the $M \& E$ industry, and indirect tax being a transaction tax impacts the industry almost at every single stage. With the advent of GST, things are expected to become relatively simpler for the entertainment industry as it would be subject to only one tax and permissible local body taxes. The GST legislation considers cinema as a luxury and puts it under the highest tax rate of $28 \%$. Given the socioeconomic developments round the world, the cinema may not really be a luxury, at least in metro cities. Sporting events like IPL also attract a 28\% GST levy, which makes them costly However, the prices of DTH and cable services were reduced after the implementation of GST.

\section{Review of literature}


Poonam (2017) studied “Goods and Services Tax in India: An Introductory Study' and concluded that GST would be a really necessary step in the field of indirect taxation. The paper has tried to relinquish information concerning GST system. She in her research paper additionally quoted that Consumer's tax burden can just about scale back to $25 \%$ to $30 \%$. Indian manufactured products would become a lot more competitive in the domestic and international markets. This taxation system would instantly encourage economic growth. GST will prove easier to administer due to its transparency.

Lourdunathan and Xavier (2017) studied "A study on implementation of goods and services tax (GST) in India: Prospectus and challenges" and concluded that GST will bring One Nation and One Tax market. GST and its efficient formulation and functioning will lead to resource and revenue gains for both Centre and States majorly through widening of tax net and improvements in tax compliance. They suggested in their research paper that it is necessary on the part of the government to educate, conduct proper training, continuous seminars and workshop on GST is need of the hour. Thus, necessary steps should be taken.

Shefali (2016) studied "A Research Paper on an Impact of Goods and Service Tax (GST) on Indian Economy" and found that GST will simplify existing indirect tax system and will help removing inefficiencies created because of the heterogeneous taxation system in the previous regime only if there is a clear consensus over issues of threshold limit, revenue rate, and inclusion of petroleum products, electricity, liquor and real estate. The government should refrain from implementing such regime, until the consensus is reached.

Akanksha and Aastha (2016) in their article named "Goods and Services Tax in India - A Positive Reform for Indirect Tax System" that GST will provide relief to producers and consumers as it provides wide and comprehensive coverage of input tax credit set-off, service tax set off and subsuming the several taxes. Formulation and implementation of GST efficiently will lead to resource and revenue gain for both Centre and States majorly through widening of tax base and improvement in tax compliance. They further concluded that GST will have a positive impact on various sectors and industry in the long run. Although implementation of GST requires concentrated efforts of all stake holders namely, Central and State Government, trade and industry. Thus, necessary steps should be taken.

Monika And Upasana (2015) studied "GST in India: A Key Tax Reform" and concluded that implementation of GST provides a simple, user- friendly and transparent tax system. GST stands for a coherent tax system which will colligate most of current indirect taxes and in 
long term it will lead to higher output, more employment opportunities and flourish GDP by $1-1.5 \%$. If implemented successfully, it can also be used as an effective tool for fiscal policy management due to nation-wide same tax rate. Its execution will also result in lower cost of doing business.

Nishita (2014) examined "Goods and Service Tax: It's Impact on Indian Economy", and concluded in her research paper that GST is not simply VAT plus service tax, but a major improvement over the previous system of indirect taxation system in India; a justified step forward. She also stated that a single rate would help to maintain simplicity and transparency by treating all goods and services as equal without giving special treatment to some 'special' goods and/or services.

Nitin (2014) examined, "Goods and Service Tax- A Way Forward" and opined that implementation of GST in India will help in removing economic distortion created by previous indirect tax system and is expected to encourage unbiased tax structure which is same throughout all geographical locations in India.

\section{Research gap}

Although there have been several research works done in the field of GST at recent times regarding the history of its implementation, the aftereffects and how it is beneficial for different sectors of the economy, not much focus has been given to the media and entertainment industries, the kind of problems they are facing and how they are tackling with the changeover. Therefore, this paper is an attempt to analyse the impact of GST on this sector.

\section{Objectives of the study}

The study is based on the following objectives:

(i) To get an overview of GST system and media and entertainment sector in India.

(ii) To understand the impact of GST on media and entertainment sector.

(iii) To cognise the present challenges of the same and provide a few suggestions to overcome the challenges.

\section{Impact of GST on M\&E sector}

5.1.On supplies made by producers -Before the GST regime, temporary transfer or permitting the use or enjoyment of a copyright was covered under sub-section 13(1)(a) and (b) of the Indian Copyright Act, 1957, relating to original literary, 
dramatic, musical or artistic works or cinematograph films, and was exempted from Service Tax. Under GST, this exemption has been taken away. The supply of all the intellectual property rights (in respect of goods other than computer software) attract GST at the rate of $12 \%$. Permanent transfer of copyrights was considered as deemed sales and was therefore chargeable to VAT (subject to state-wise exemptions), while the same was not taxable under the service tax laws. Both permanent and temporary transfer is taxable at an equivalent rate of $12 \%$ under GST. This necessitates an increase in working capital requirement for the producers as the monetary outflow in the form of taxes has increased. However, GST has also opened up the scope for increased availability of input tax credit. The credit of taxes paid in goods can now be used for payment of liability on services, which was not available before. The rest of the routine supplies by the producer, such as renting services, sale of old costumes, sponsorship and partnership services, etc. attract $18 \%$ GST as compared to $15 \%$ Service Tax in the old indirect taxation regime.

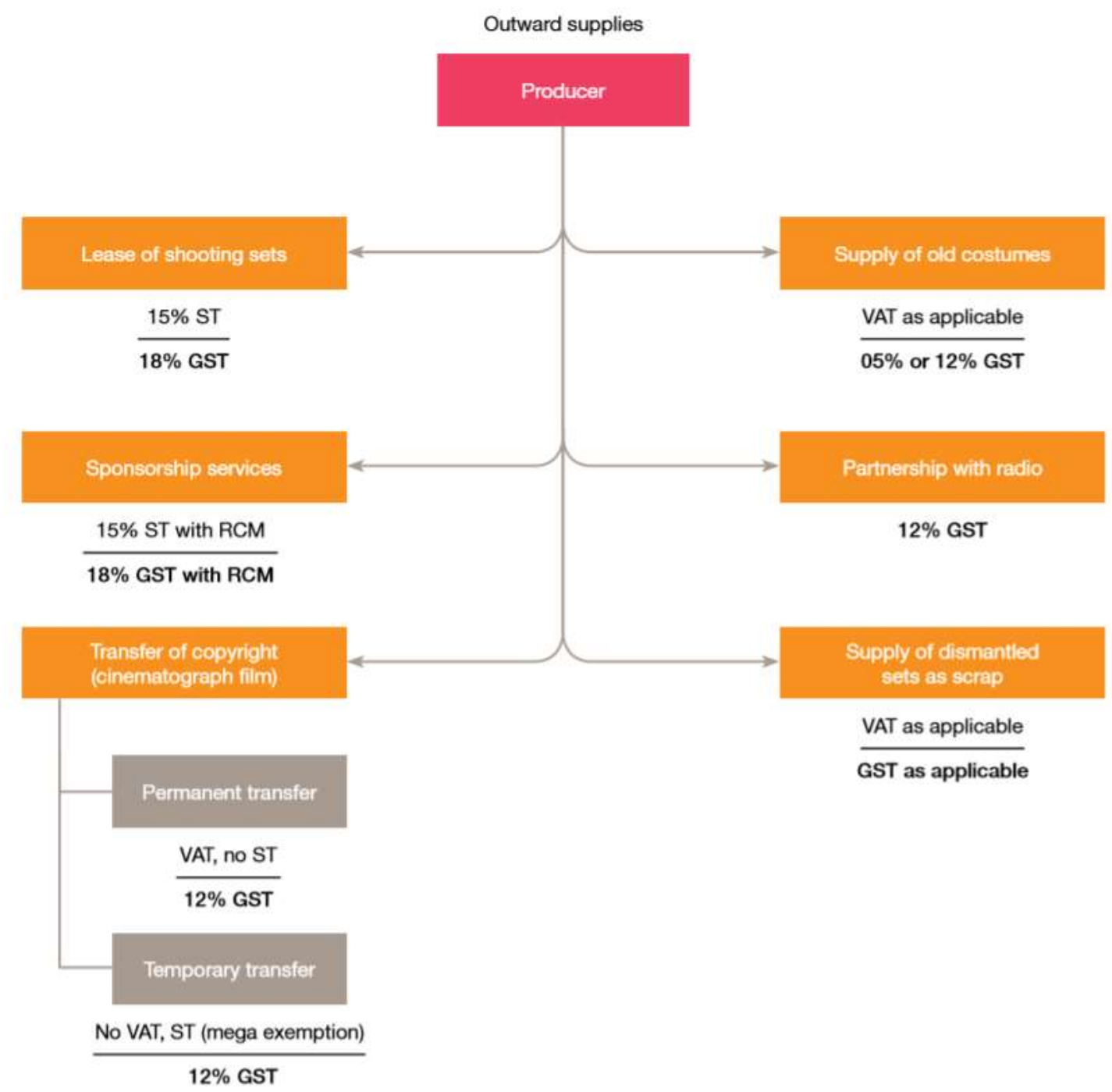


Source: Report by PWC and ASSOCHAM India

5.2.On supplies received by producers -The earlier indirect tax regime did not allow setoff of input tax credit of taxes paid on services against the tax liability for manufacturing goods and vice-versa. With the seamless credit facility under GST regime, it has been made possible and hence that the credit base of producers is likely to expand. At the same time, the increased default rate of tax on services from $15 \%$ Service Tax to $18 \%$ GST has caused an impending cash outflow. There is a change in the measure of taxation under GST. For instance, services such as temporary transfer of copyright by an author, music composer or photographer relating to an original literary, dramatic, musical or artistic work, which were earlier exempt from Service Tax, are now taxable under reverse charges in the hands of the recipient. The producer is entitled to avail input tax credit of taxes paid on all procurements for business purposes, except for a few cases such as food, beverages, outdoor catering and vehicle hire.

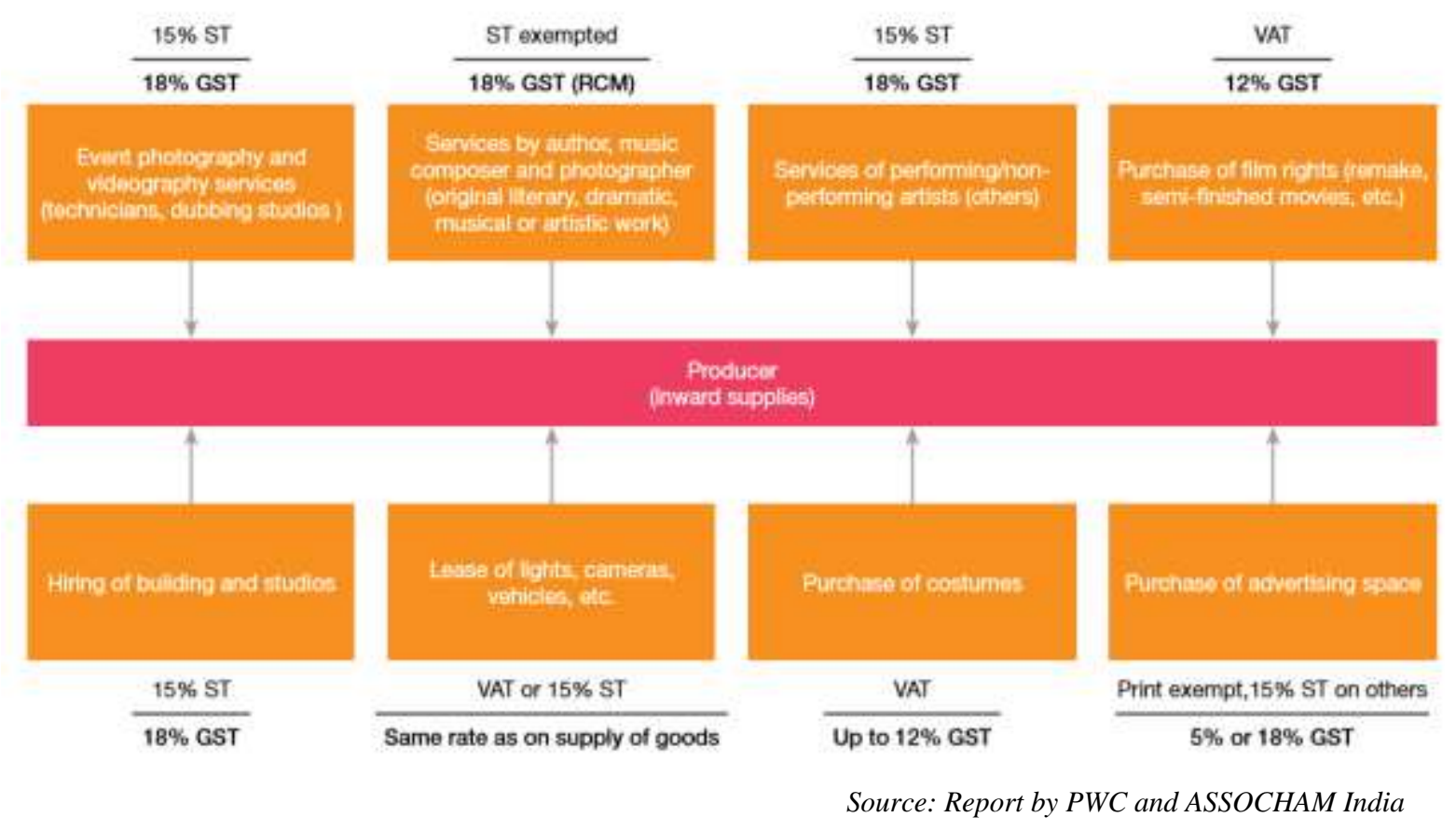

5.3.On supplies made by studios - Studios provide both pre-production and postproduction facilities to the producers of various shows in the audio-visual medias. Pre-production facilities include renting of shooting sets, studios, providing generator sets on hire basis etc. Renting of such generator sets, without transfer and effective control, was treated as 'supply of tangible goods' and classified as services; hence was subject to service tax. However, such renting of such generator sets, with transfer and effective control, was treated as right to use, and considered as deemed sales for 
VAT purposes. Now, both come under the purview of GST @ 18\% as compared to 15\% Service Tax and applicable rate of VAT charged earlier for most of such supplies.

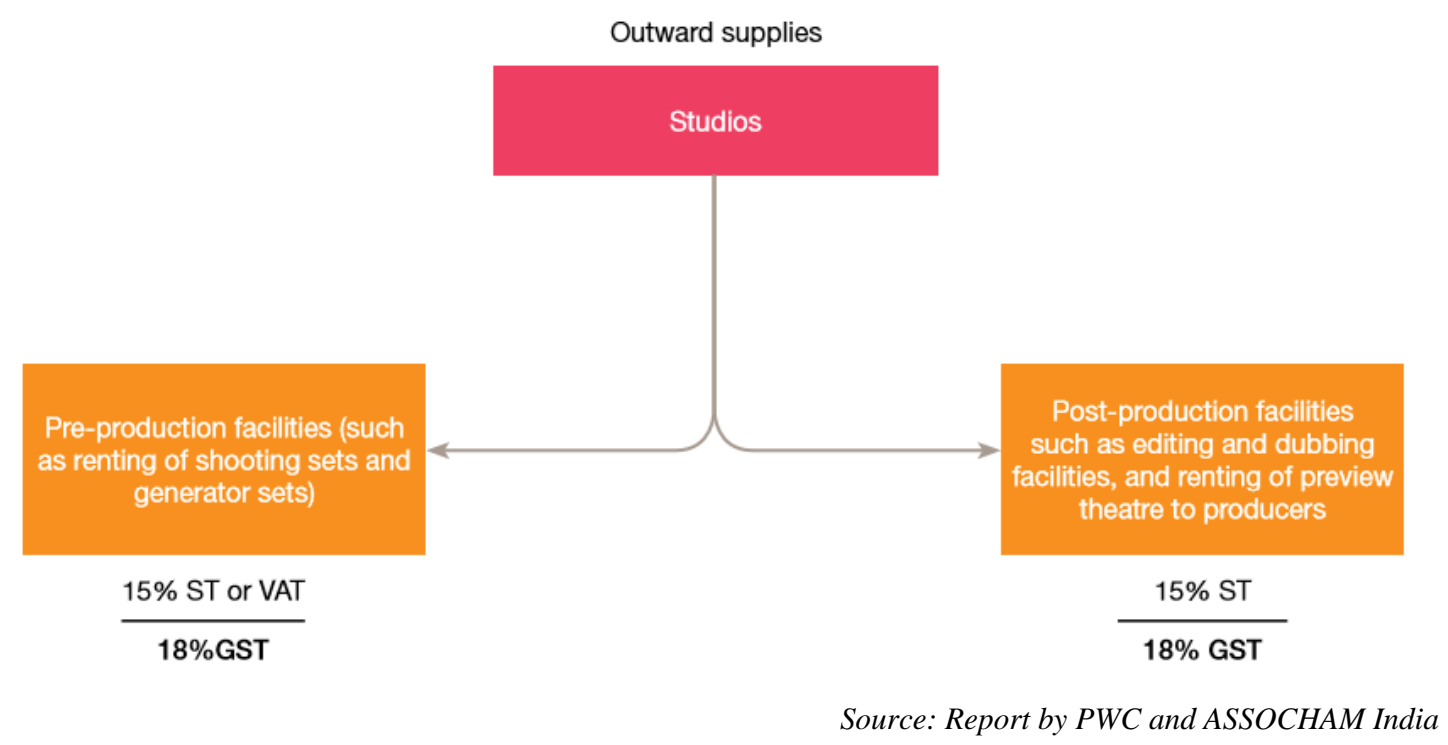

5.4.On supplies received by studios -The major input cost of the studios involves maintenance of the sets and studios. The studios procure goods and services from third-party vendors for maintenance purpose which were earlier subject to applicable VAT rates or $15 \%$ service tax, as the case may be. These procurements are now subject to GST, and the input tax paid on procurement of the goods can now be used as GST credit to set off GST liability on renting of shooting sets and preview theatres. Studios also incur a major cost on electricity, which was outside VAT and service tax earlier and continues to be so even under the GST regime. In case studios entering into a works contract for building, construction, fabrication, erection, installation, fitting out, improvement, modification, repair, maintenance, renovation etc., of any immovable property wherein transfer of property in goods is involved in the execution of such contract, then it is treated as a supply of services (works contract) in GST. Such works contracts were earlier subject to VAT and service tax using different methods for composition and valuation. 


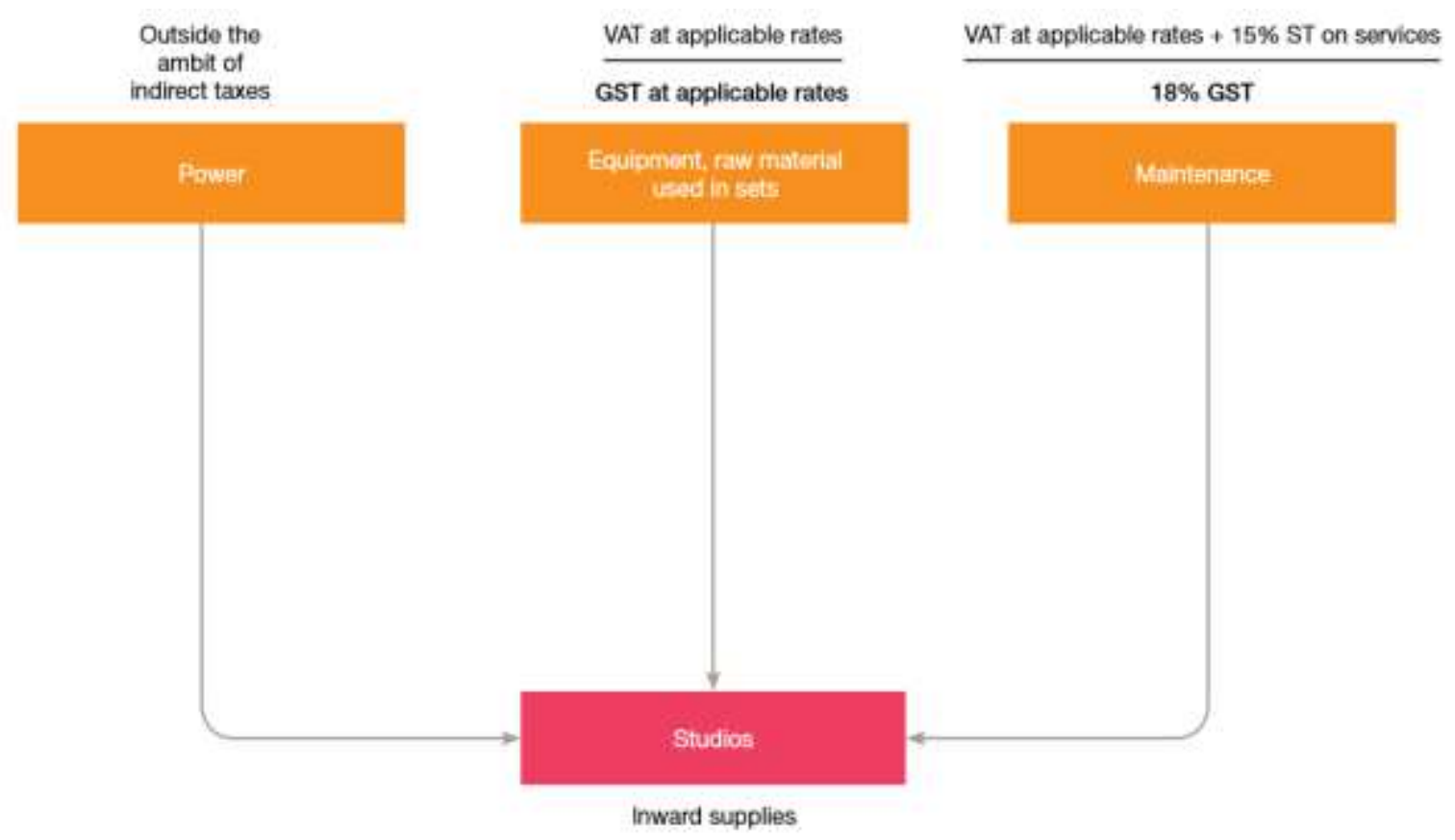

Source: Report by PWC and ASSOCHAM India

5.5.On supplies made by distributors -The distributor is the second important aspect of the industry. He purchases the rights from the producer for further distribution. In the pre-GST regime, the permanent and temporary transfer of film rights were taxed differently. There was a levy of VAT but no service taxon permanent transfer of rights, whereas in case of temporary transfer, the industry enjoyed exemption from both service tax and VAT. Under the principal-to-principal arrangement, when a movie is exhibited by the theatre owner on his own account (i.e., the copyrights are transferred), the distributor will charge $12 \%$ GST on the supply of copyrights, which was earlier exempted from service tax as transfer of cinematograph films. Alternatively, the distributor can take the theatre on hire from the theatre owner and exhibit the movie. In this case, the theatre owner will charge GST for providing renting services and the distributor will charge GST on the sale of movie tickets. Under the third option, i.e. partnership, joint and collaboration, typically no services are rendered by the distributor to the theatre owner or vice versa, it being a revenue sharing arrangement. It was not subject to tax in the pre-GST regime, and shall also not attract GST in the absence of any underlying service. On the sale of movie tickets, there was a state-specific Entertainment Tax ranging from 15\% to $110 \%$ (an average of $30 \%$ ). Under GST, tax at the rate of $18 \%$ is levied where the price of tickets is Rs. 100 or less and $28 \%$ in other cases. Also, the municipal and local bodies are allowed 
to levy a parallel Entertainment Tax along with GST varying from state to state, putting an additional tax burden on the end users.

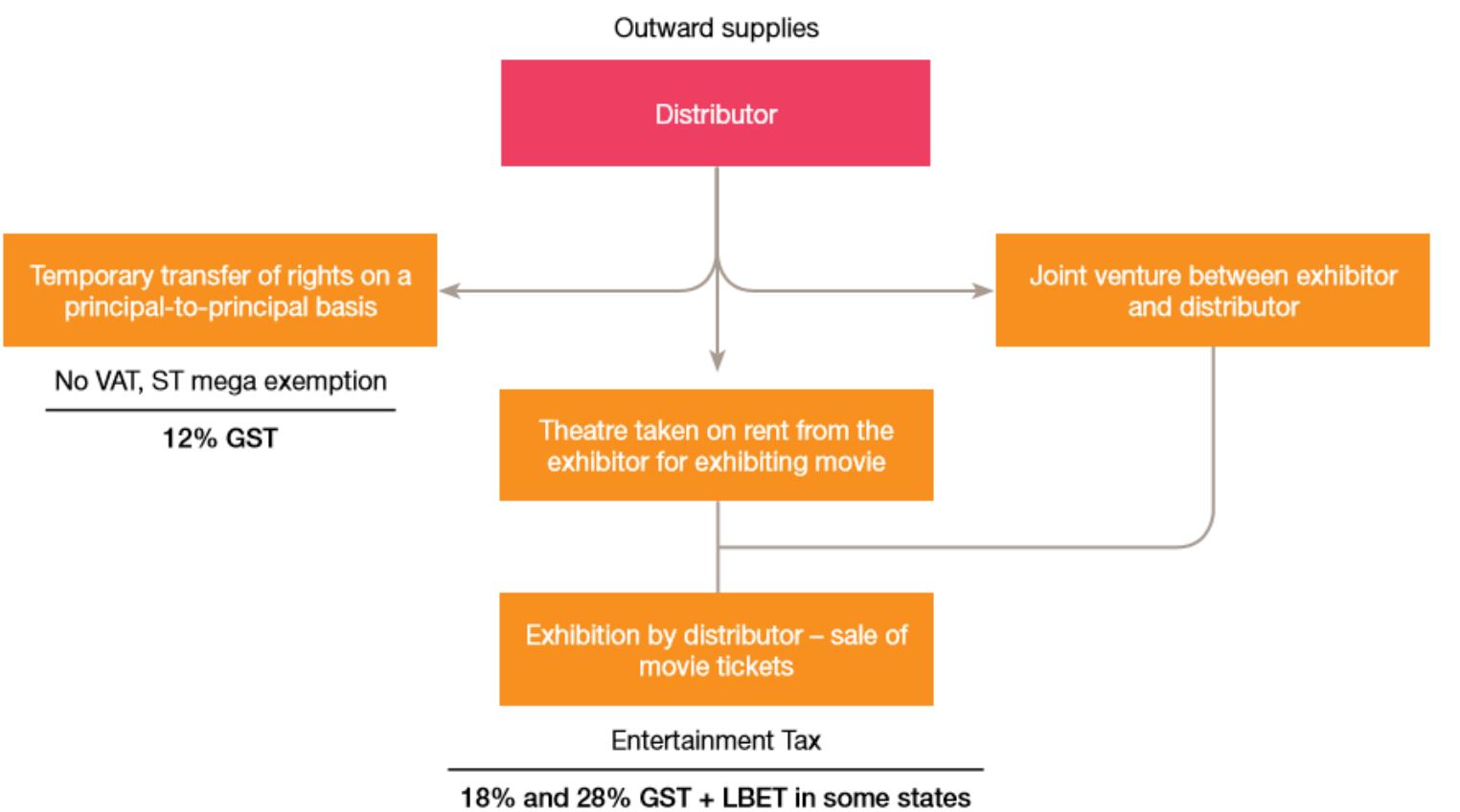

Source: Report by PWC and ASSOCHAM India

5.6.On supplies received by distributors - The major input cost in the hands of the distributor includes procurement of broadcasting rights, rental expense of theatres, digital transmission expenses, advertisement cost and other support services. With the withdrawal of the exemption on the transfer of copyright on cinematographic films, the service becomes taxable, and the input tax charged by the producer will be used by film distributors against their output tax liability. Print media advertising was exempted, while the other modes of advertisements were subject to $15 \%$ service tax. The exemption has been withdrawn now; thus, the procurements are likely to become costlier with the levy of 5\% GST. All other advertising services attract 18\% GST causing 3\% increase of tax burden in the GST regime. As taxes paid on these expenses are creditable, this may not result in any additional cost burden to the distributor. 


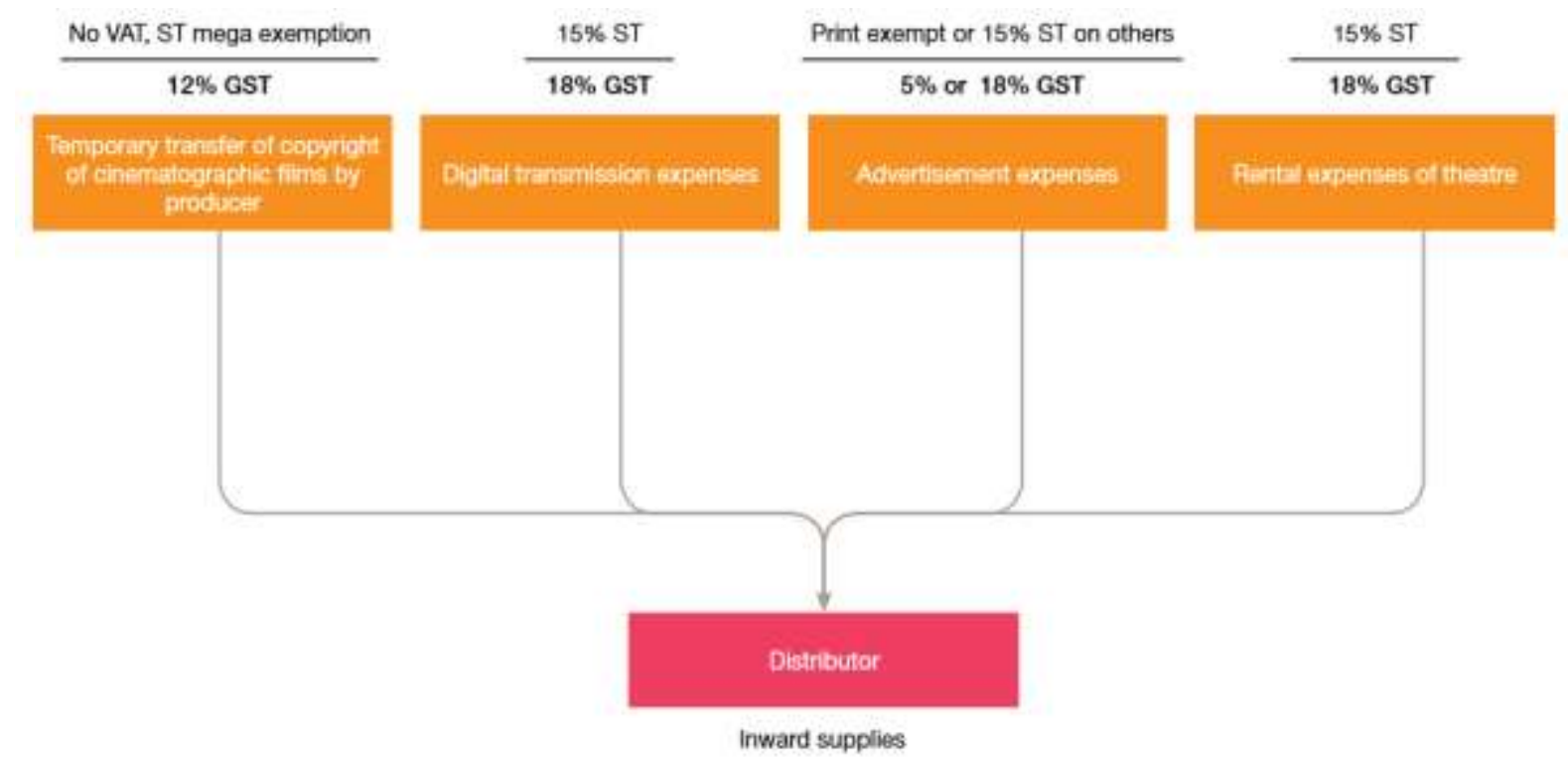

Source: Report by PWC and ASSOCHAM India

5.7.On supplies made by exhibitors - An exhibitor screens a film for the audience and hence has the most important role in the value chain. They either acquire the cinematographic film's rights temporarily/permanently from the distributor or rent out the theatre they own for exhibit of movies or may enter into a revenue arrangement with the distributor. Under the first arrangement the exhibitor earns from the sale of movie tickets. Earlier, the sale of movie tickets used to attract Entertainment Tax ranging from $15 \%$ to $110 \%$ (with an average of $30 \%$ ), based on the state laws. Under GST, the sale (supply) of movie tickets is subject to a tax rate of $18 \%$ where the price is up to Rs. 100 , and to a rate of $28 \%$ in cases where the price is above Rs. 100 . Also, the local bodies continue to have the power to levy and collect tax on entertainment and amusement. Under the second arrangement, the theatre owner rents the cinema hall to the distributor. This was earlier taxable at $15 \%$ and is now be taxable at $18 \%$ under GST. Under the third scheme; i.e., a revenue-sharing arrangement, there is no supply between the distributor and exhibitor; therefore, the transaction is unlikely to attract GST. A theatre owner may also earn from the supply of advertisement space, earning of sales commission from online booking platforms, and supply of food and beverages over the counters at the theatre which was subject to dual levy of VAT and service tax under pre-GST circumstances. Under GST regime, the supply of food and/or beverages is taxable at the rate of $5 \%$ with no input tax credit facility. 


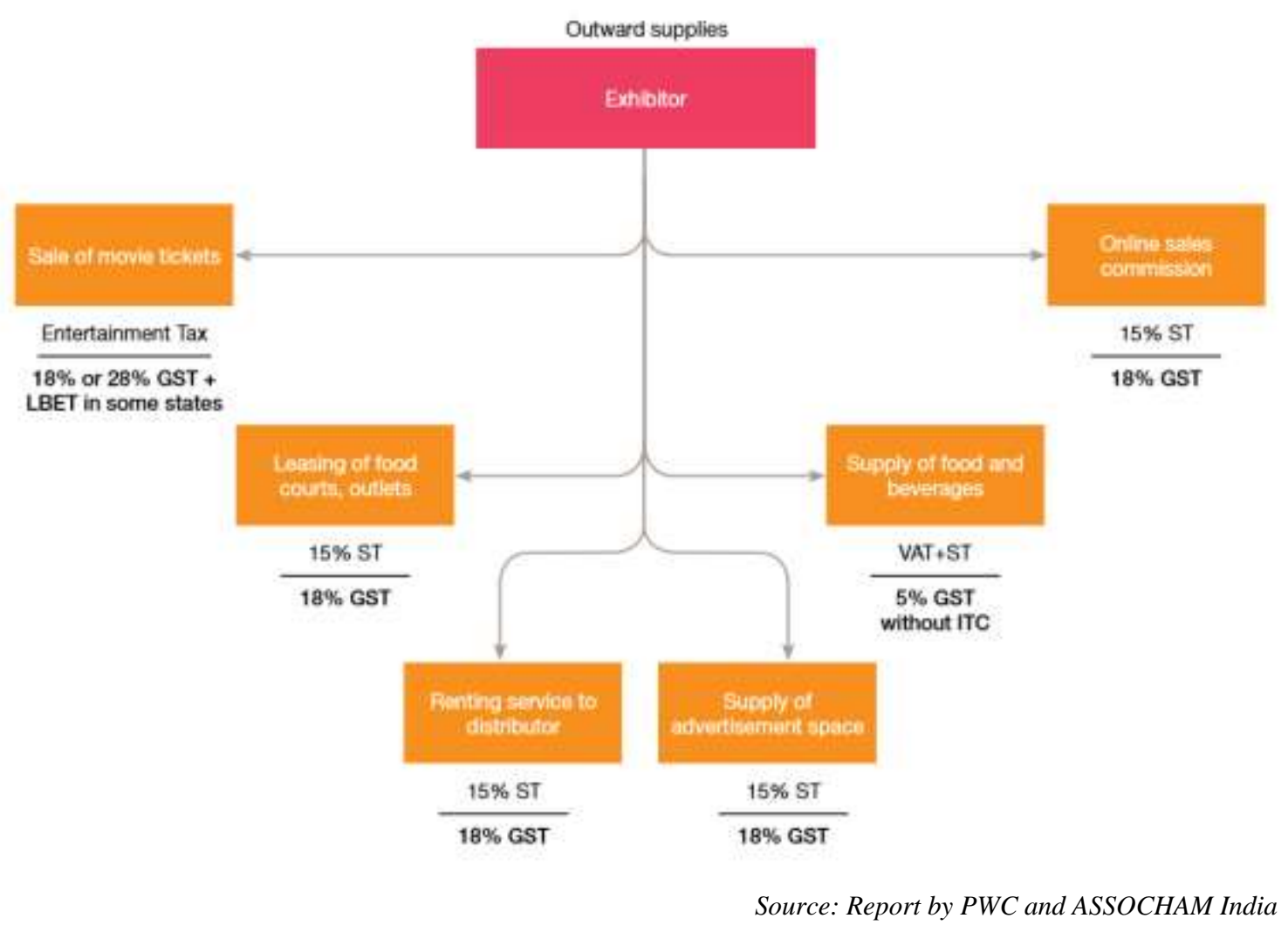

5.8.On supplies received by exhibitors -A theatre owner incurs a huge amount of expenditure towards the procurement of broadcasting rights, contract staffing, digital transmission, leasing of equipment, rental expenses, annual maintenance expenses, etc.to maintain and provide the comfort and entertainment to meet the expectations of the audience. Earlier, as there was only Entertainment Tax on the sale of tickets, no set-off of service tax or VAT paid by exhibitors on the procurements was allowed. With the introduction of GST, Entertainment Tax is subsumed and may reduce the final cost of tickets due to the seamless input tax credit mechanism available in the value chain at every level. Under pre-GST regime tax on the supply of manpower or security service was under reverse charge. However, under GST, tax on said supply is payable under forward charge. With the introduction of GST on the procurement of rights and a general increase in the tax rate on services by $3 \%$, exhibitors have experienced an increased tax burden on procurements. 


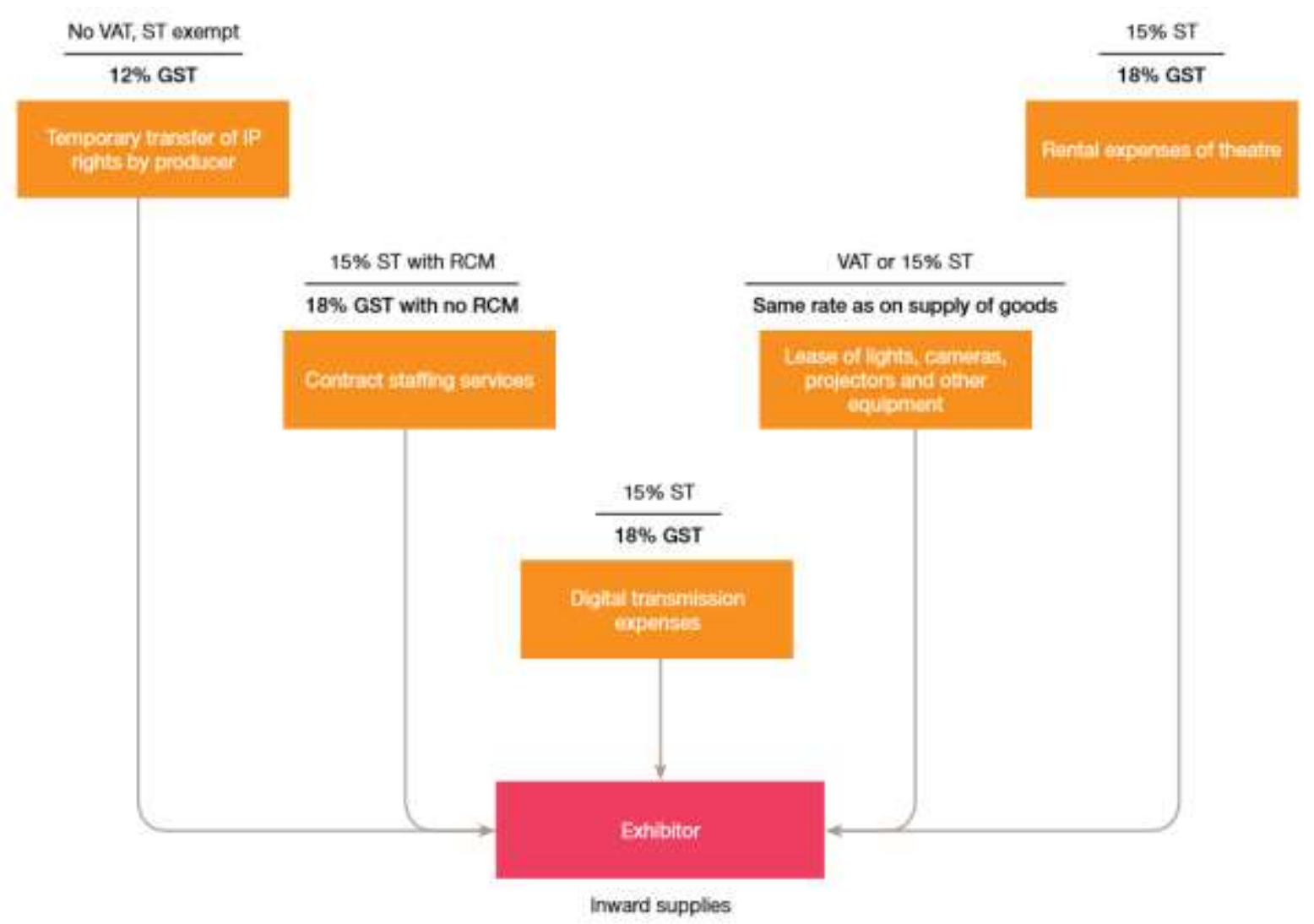

Source: Report by PWC and ASSOCHAM India

5.9.On other activities -In case of services rendered by artists, service tax was applicable @ $15 \%$ on forward charge basis which under GST became $18 \%$ and services rendered by technicians like composers, photographers, service tax was applicable @ 15\% on forward charge basis but under GST it became 18\% GST on reverse charge basis. Artists now have to pay more tax due to increased tax rate under GST on services, while burden on technicians like composers, photographers is nullified; burden on producers has increased due to reverse charge tax under GST. Similarly, sponsorship and brand promotion was subjected to $15 \%$ tax previously, which under GST increased to $18 \%$, thereby increasing the tax burden.

\section{Current challenges}

(i) Additional compliance burden on Media and Entertainment sector as certain services for this sector which were exempt under the pre-GST regime have now been brought under the tax ambit.

(ii) Earlier, the temporary transfer or permitting the use or enjoyment of a copyright covered under sub-section 13(1)(a) and (b) of the Indian Copyright Act, 1957, relating to original literary, dramatic, musical or artistic works or cinematograph 
films was exempt; but it is now subject to GST. Moreover, these services have now been made taxable in the hands of the recipient. This would lead to an additional burden on the recipient as payment of tax under reverse charge requires raising of a self-invoice and other necessary disclosures in returns.

(iii) Further, the scope of taxability on services which are put to tax under reverse charge is expanded with the use of the words 'the like' in the notification. This has led to some confusion about which all services, other than those mentioned in the notification, would be taxed under reverse charge basis.

(iv) There is likely to be a room for different interpretations and this might result in unwarranted litigation.

\section{Suggestions}

(i) LBET, a levy imposed by some of the municipal bodies, should come under GST just like other municipal levies such as octroi which is already subsumed to promote seamless credit.

(ii) An option should be given to restaurants, including eating joints and food outlets in theatres, to use input tax credit, which they are not allowed to use at present.

(iii) The $28 \%$ GST rate on tickets above Rs. 100 should be rationalised, as done for amusement parks.

(iv) There should be further pruning of tax rates. Currently, there are almost half a dozen rates on goods and services. A consolidation of the rate structure should be considered.

(v) Simplification of GST compliance related requirements, including tax payments and returns.

(vi) Simplification and integration of e-way bill (a document required for movement of goods).

(vii) Presently, GST suffers from different ambiguities and loopholes to an extent. Moreover, certain provisions of GST seem to contradict the objective with which they were brought into existence. These need to be addressed at the earliest.

(viii) The concept and availability of input tax credit have been liberalised as compared to earlier provisions; however, there are still certain restrictions. There needs to be free availability of input tax credit without any restriction or conditions.

(ix) The common portal (www.gst.gov.in) should be further simplified, made more user-friendly and offer added flexibility for common people's understanding. 
(x) Tax disputes could prove to be a major disruption in any business environment. The government should focus on strengthening the judicial discipline and minimise the tax disputes under GST. The recent budget proposal on time-bound adjudication in the customs law should be extended to GST as well.

(xi) There should be a focus on tax administration; the legal sanctity of tax laws resides only in acts, rules and notifications. Under GST, there is an overload of information and views in the public domain in the form of FAQs, tweets and eflyers, giving conflicting answers and diluting the faith of a taxpayer.

\section{Conclusion}

To conclude, it may be said that though the present GST system sounds flawless on paper, but in reality, it is not. It has irrational differential tax rates and procedural bottlenecks. Also, a major fear with the current GST structure is that it would allow local municipalities to decide the tax rate on movies. A key exemption has been taken away, namely on transfer of IP relating to original literary, dramatic, musical or artistic works or cinematograph films which as available earlier. Moreover, the recipient of certain services now would face working capital crunch due to services being subject to tax under reverse charge basis in the recipient's hand. But on a general note, the GST regime does much good than harm, as it empowers both the centre and the states to levy GST. This could not be done previously, as the centre did not have the power to impose any sort of tax on goods beyond the manufacturing process, while the state could not tax services. GST has not only amalgamated several types of indirect taxes into one in order to remove cascading effect, but also has reduced the overall tax burden on consumers. It is considered to be a much simple tax regime in terms of compliance and administration as compared to its predecessor. Moreover, now tax paid on procurement of goods can be used as credit for payment of output tax liability on providing services and vice versa. Thus, GST in every way is a better solution than the previous tax regime. However, the existing tax rates and its procedure of implementation including the compliance system attract certain controversies. Keeping in mind that GST is at its nascent stage, if necessary, modifications are made in the regulations, it can provide Media and Entertainment sector an edge in growth over the previous system of taxation. 


\section{$\underline{\text { References }}$}

\section{Books and articles:}

[1] Ahamad, E. \&Poddar, S. (2009). Goods and Service Tax Reforms and Intergovernmental Consideration in India. Asia Research Center. LSE,2009.

[2] Jayashree R, Kotnal. GST In India: An enrichment of indirect taxation system, International Journal of applied Research. 2016; 2(4):735-738.

[3] Garg, G. (2014). Basic Concepts and Features of Good and Service Tax in India.

[4] Kamna, S., Pinki, Verma, R. (July 2014). Good and Service Tax - Panacea for Indirect Tax System In India. Tactful Management Research Journal. Vol. 2, Issue 10.

[5] Kumar, N. (May 2014). Goods and Service Tax in India-A Way Forward. Global Journal of Multidisciplinary Studies. Vol. 3, Issue 6.

[6] Mawuli, A. (2014): “Goods and Service Tax- An Appraisal”Paper presented at the the PNG Taxation Research and Review Symposium, Holiday Inn, Port Moresby, 29-30.

[7] National Council of Applied Economic Research Final Report. Moving to Goods and Services Tax in India: Impact on India's Growth and International Trade, prepared for Thirteenth Finance Commission Government of India.

[8] Vasanthagopal, R. (April 2011). GST in India: A Big Leap in the Indirect Taxation System. International Journal of Trade, Economics and Finance, Vol. 2, No. 2.

\section{Websites:}

[1] http://www.onlinegst.in/impact-of-gst-on-M\&E/

[2] http://www.gstindia.com/gst-to-help-reorient-states-towards-media-entertainment-panel/

[3] http://en.wikipedia.org/wiki/Goods_and_Services_Tax_(India)

[4] http://taxguru.in/goods-and-service-tax/impact-gst-imports.html

[5] http://economictimes.indiatimes.com/topic/GST

[6] http://www.moneycontrol.com/newstopic/gst/ 